Volume I Tahun 2021

November 2021

\author{
E-ISSN: 2808-5361 \\ http://e-journal.fkmumj.ac.id/
}

Proceeding The First

Muhammadiyah InternasionalPublic Health and Medicine Conference

\title{
Behavior Increase Body Immunity
}

\author{
Sri Mayasari Puspa \\ Sentra Medika Hospital \\ Mayor Oking Jayaatmaja St, No. 9, 16911, Bogor, West Java \\ E-mail: puspasri01@gmail.com
}

\begin{abstract}
Covid-19 has spread to several countries including Indonesia. Responding to the growing trend of spreading and contagion of Covid-19, which has continued to increase, since April 2020. The Covid-19 pandemic has become a disruption so we need to recognize, overcome, and prevent this uncertainty so that this uncertainty will end soon To provide advice to all levels of society to be alert to the Covid-19 outbreak as an effort to reduce the spread of the Covid-19 outbreak, one of which is to increase body immunity. The method used in this study is a survey method used to analyze the role of employees of Cibinong Sentra Medika Hospital in increasing body immunity. The survey results showed that the average "yes" answer was above 70\% on the understanding and knowledge employees of Cibinong Sentra Medika Hospital about the Covid-19 virus and how to increase body immunity. The knowledge employees of Cibinong Sentra Medika Hospital about Covid 19 and community behavior regarding the prevention and transmission of Covid-19 is in a good category. This condition has become a good strength for employees of Cibinong Sentra Medika Hospital in the Covid-19 handling program. Efforts to prevent and monitor the spread of Covid-19 must continue to be carried out by various parties, in various locations/office environments or community associations/public places, including their respective communities/individuals so that there is no increase in the number of serious cases. The public is advised not to stress easily in the face of this uncertain situation during the Covid-19 pandemic.
\end{abstract}

Keywords: Covid-19, Body Immunity, New Normal 


\section{INTRODUCTION}

Coronavirus or severe acute respiratory syndrome coronavirus 2 (SARS-CoV-2) is a virus that attacks the respiratory system. The disease caused by this viral infection is called COVID-19. Coronavirus can cause mild disorders of the respiratory system, severe lung infections, and even death. Severe acute respiratory better known as the Corona virus is a new type of coronavirus that is transmitted to humans. This virus can attack anyone, such as the elderly (older people), adults, children, and infants, including pregnant women and breastfeeding mothers. Corona virus infection is called COVID 19 (Corona Virus Disease 2019) and was first discovered in the city of Wuhan, China at the end of December 2019. This virus spreads very quickly and has spread to almost all countries, including Indonesia, in just a few months. This has made several countries implement policies to impose lockdowns to prevent the spread of the Coronavirus. In Indonesia itself, a Large-Scale Social Restriction (PSBB) policy was implemented to suppress the spread of this virus.

New normal is a scenario to accelerate the handling of COVID-19 in health and socioeconomic aspects. The Indonesian government has announced plans to implement a new normal scenario taking into account epidemiological studies and regional preparedness. This means that people must live a new normal life until next year, even more, until this pandemic is declared over. Changes in behavior will be the key to optimism in dealing with Covid-19 by implementing health protocols as recommended by the government or known as the new normal. Therefore, people must always live clean and healthy to avoid coronavirus. One way to prevent the coronavirus is by the community must increase the body's immunity, there are many ways to increase the body's immunity by eating nutritious food, thinking positively, and exercising diligently Exercising has also been shown to increase endurance and reduce inflammation. However, it is also necessary to know that exercise that is done regularly has a better effect on the immune system than exercise that is only occasionally. So, make time to exercise at least 30 minutes every day.

\section{METHODS}

The research method used is a survey method. In this research, descriptive analysis is used to analyze the Behavior of Increasing Body Immunity. The population is the employees of Sentra Medika Cibinong Hospital. Data were collected using interviews and observing the daily behavior of employees.

\section{RESULTS AND DISCUSSIONS}

The knowledge employees of Cibinong Sentra Medika Hospital regarding Covid-19 is very high. The results of research related to the role of society in breaking the Covid-19 chain are in line with research conducted by Yanti B, et al (2020) which states that $99 \%$ of Indonesians have good knowledge, $59 \%$ have a positive attitude and $93 \%$ have positive behavior. good for efforts to prevent 
Covid-19 in Indonesia. The role of people who have good knowledge will be easier to break the spread of COVID-19. People who already know about certain information related to COVID-19 will be able to determine and make decisions on how to deal with it. In other words, when a person has information about COVID-19, he will be able to determine how he should behave.

Table 1.1 shows the characteristics of the respondents which include as many as 30 respondents. Based on all respondents answers, information was obtained from respondents' ages ranging from 20-55 years, in an office environment.

Table 1.1 Respondents Answers on How to Increase Body Immunity

\begin{tabular}{llcc}
\hline \multirow{2}{*}{ No } & \multicolumn{1}{c}{ Question } & \multicolumn{2}{c}{ Percentage of Answers } \\
\cline { 3 - 4 } & & \multicolumn{1}{c}{ Yes } & No \\
\hline 1 & Wash your hands properly & $80 \%$ & $20 \%$ \\
2 & Practice cough and sneeze etiquette & $80 \%$ & $20 \%$ \\
3 & Always wash your hands before and after activities & $82,5 \%$ & $17,5 \%$ \\
4 & Break time 7-9 hours of the day & $90 \%$ & $10 \%$ \\
5 & Washing vegetables and fruits before eating & $82,5 \%$ & $17,5 \%$ \\
6 & Have medical equipment such as masks, hand sanitizers, & $100 \%$ & $0 \%$ \\
& and Soap & & \\
7 & Keep a distance of 1-2 meters during Travel & $80 \%$ & $20 \%$ \\
8 & Eating regularly Fruits & $77,5 \%$ & $22,5 \%$ \\
9 & Get the light the sun Enough every day & $85 \%$ & $15 \%$ \\
10 & Take vitamins C,E,D with enough & $75 \%$ & $25 \%$ \\
11 & Definitely do some indoor sports a week & $70 \%$ & $30 \%$ \\
12 & Clean and Healthy & $82,5 \%$ & $17,5 \%$ \\
13 & Understanding the meaning New Normal & $85 \%$ & $15 \%$ \\
14 & Understood Danger of Covid-19 Virus & $90 \%$ & $10 \%$ \\
\hline
\end{tabular}

From the table above, it can be concluded to what extent the understanding and knowledge of the employees of Cibinong Sentra Medika Hospital about the Covid-19 virus and how to increase body immunity. This conclusion is based on the survey results which show the average "yes" answer is above $70 \%$.

\section{CONCLUSIONS AND SUGGESTIONS}

The Covid-19 pandemic has had a good impact on new behavior in society, which is much more concerned with hygiene, health, and safety factors. Based on the results of this study, it shows that the knowledge of the employees of Cibinong Sentra Medika Hospital about Covid 19 and community behavior regarding the prevention and transmission of Covid-19 is in a good category. This condition has become a good strength for the employees of Cibinong Sentra Medika Hospital in the Covid-19 handling program. However, this survey data was obtained only in certain work environments with a limited number of respondents as well. For this reason, prevention and monitoring efforts to stop the spread of Covid-19 must continue to be carried out by various parties, in various locations/office environments or community associations/public places, including their 
respective communities/individuals so that there is no increase in the number of serious cases.

During the COVID-19 pandemic, it is hoped that the community will maintain their health, especially with sufficient body immunity by exercising and complying with health protocols. Managing stress is also important. Because stress affects the body's immunity. When someone is stressed, the body will release hormones to relieve stress. However, this condition has the effect of lowering the immune system. Therefore, the author urges the public not to be easily stressed in facing this uncertain situation during the Covid-19 pandemic.

\section{REFERENCES}

Ahmadi (2013).Kesehatan Masyarakat, teori dan aplikasi. Jakarta: Raja Grafindo

IFSW. (2020). Statement on IFSW and COVID-19". https://www.ifsw.org/statement-onifswandcovid-19/ Direktorat Jenderal Pencegahan dan Pengendalian Penyakit, Kementerian Kesehatan RI. (2020). "Pedoman Pencegahan dan Pengendalian Corona Virus Disease (COVID-19)", 2020.

Ika (2020), Efektifitas Masker Kain Cegah Covid-19, https://ugm.ac.id/id/newsPdf/19280efektivitas-masker-kain-cegah- covid- 19-paling-rendah

Ni Putu Emy Darma Yanti, I Made Arie Dharma Putra Nugraha, Gede Adi Wisnawa, Ni Putu Dian Agustina, Ni Putu Arsita Diantari. Gambaran Pengetahuan Masyarakat Tentang Covid-19 Dan Perilaku Masyrakat Di Masa Pandemi Covid-19. Jurnal Keperawatan Jiwa. 2020

Listiana, O., Sholikhati, D. I. K., \& Fatimah, I.S. (2020). Edukasi Corona Virus Desease 10 (COVID19) Melalui penyebaran Poster Kepada Mayarakat Kecamatan

Faura Dea Ayu Pinasti. Analisis Dampak Pandemi Corona Virus Terhadap Tingkat Kesadaran Masyarakat dalam Penerapan Protokol Kesehatan. 2020

Slawi Kabupaten Tegal. JABI: Jurnal Abdimas Bhakti Indonesia, 1(2), 10-10.

Isfauzi Hadi Nugroho. Penerapan Protokol Kesehatan Di Era Kenormalan Baru Pada Dunia.2020

WHO (2020). Corona Virus (Covid-19) outbreak,https://www.who.int/ emergencies/diseases/novelcoronavirus-2019

Devi Pramitra Sari, Nabila Sholihah 'Atiqoh. Hubungan Antara Pengetahuan Masyarakat Dengan Kepatuhan Penggunaan Masker Sebagai Upaya Pencegahan Covid-19. INFOKES,. 2020

WHO (2020) Coronavirus disease (covid- 19) Situation Report-114, May 13, 2020

Syafrida, Ralang Hartat. Bersama Melawan Virus Covid-19 di Indonesia. Jurnal Sosial \& Budaya Syar-i.2020

Yanti B, Eko Wahyudi, Wahiduddin dkk (2020),Community Knowledge, Attitudes, And Behavior Towards

Social Distancing Policy As Prevention Transmission Of Covid-19 In Indonesia, JAKI (Jurnal Administrasi Kesehatan Indonesia) Volume 8 (2020). 